\title{
FIELD TESTING AND DYNAMIC ANALYSIS OF OLD CONTINUOUS TRUSS STEEL BRIDGE
}

\author{
Artūras KILIKEVIČIUS ${ }^{1}$, Darius BAČINSKAS ${ }^{2}$, Mindaugas JUREVIČIUSS ${ }^{3}$, \\ Kristina KILIKEVIČIENE ${ }^{4}$, Antanas FURSENKO ${ }^{5}$, Jonas JAKAITIS ${ }^{6}$, Eligijus TOLOČKA ${ }^{7 *}$ \\ ${ }^{1}$ Institute of Mechanical Science, Vilnius Gediminas Technical University, \\ J. Basanavičiaus g. 28, Vilnius 03224, Lithuania \\ ${ }^{2}$ Dept of Reinforced Concrete Structures and Geotechnique, Vilnius Gediminas Technical University, \\ Sauletekio al. 11, Vilnius 10223, Lithuania \\ 3,4,5,7 Dept of Mechanics and Materials Engineering, Vilnius Gediminas Technical University, \\ Basanavičiaus g. 28, Vilnius 03224, Lithuania \\ ${ }^{6}$ Dept of Design, Vilnius Gediminas Technical University, Pylimo g. 26/Traku str. 1, Vilnius 01132, Lithuania
}

Received 05 June 2017; accepted 19 September 2017

\begin{abstract}
Paper presents dynamic field test and analysis results of a three span railway steel continuous truss bridge over river Neris in Jonava. Bridge was originally constructed in 1914. In the period of the World War II and afterwards the bridge was many time destroyed by German and Soviet armies. In 1948 the new railway bridge was constructed. Object of the present paper is to evaluate dynamic behaviour of the railway bridge after 67 years in service. Experimental dynamic analysis was divided into resonance-vibration, forced-vibration and free vibration studies. Resonance-vibrations of the bridge were excited by separate actions of shock loading and standard locomotive 2M62. Forced-vibrations were measured under the action of locomotive 2M62. Additionally, free vibration tests under passage of freight and passenger trains have been carried out. Structural dynamic response of the bridge was analysed using Brüel \& Kjær LAN XI dynamic test system and software. As a result, main dynamic parameters of the bridge were obtained. The main results include: mode shapes, frequencies of natural and forced vibrations, damping ratios, maximum amplitudes of accelerations, dynamic displacements. The obtained values were compared to the requirements of different design codes. Based on the achieved results concluding remarks and recommendations regarding the condition of the bridge after long-term period in service were presented.
\end{abstract}

Keywords: dynamic displacement, dynamic testing, heritage, modal analysis, railway bridge, still bridge.

\section{Introduction}

Engineering infrastructure of transport links is a prerequisite to creating value for public socio-cultural, economic and aesthetic of the material environment and high quality of life standards develop. In a broad sense, public infrastructure satisfies the natural and social needs, enables to organize the functional use of material environment objects as well as their targeted adaptation, quality environment development. The particular purpose of infrastructure issues and its influence on the different areas of public life encourages scientists to analyse both the possibility of modern innovative solutions and problems of historical objects adaptability to the needs of nowadays. Demand for connections harmony investigation of historical objects is definitely important, in terms of contemporary functional, aesthetic and material extension of opportunities and usage of the constructive solutions. It is also important to evaluate post-modern society's altered practical approach into the shift of philosophical paradigm of material environment and re-design, in order to protect the environment in the context of achievements of the modern technology and innovation. The usage of results of such research is relevant trying to both increasing prosperity for society and creating the identity of the area for national, regional or European Union (EU) wide.

In the scientific literature the research of engineering infrastructure problems, as objects ensure of applied arts and technical aesthetics, including metal structures, the impact on for both countries and regions economic and social development, is still new.

${ }^{*}$ Corresponding author. E-mail: eligijus.tolocka@vgtu.lt

This is an Open Access article distributed under the terms of the Creative Commons Attribution License (http://creativecommons.org/licenses/by/4.0/), which permits unrestricted use, distribution, and reproduction in any medium, provided the original author and source are credited. 
However, it is still conservatively assessed in the context of sunrise of Industrial Revolution (Ruskin, 1989), which encouraged the significant technological, economic and social changes in second half of the $18^{\text {th }}$ century (Figures 1-2). John Ruskin (1819-1900) as one of the most prominent theorists of the middle of the nineteenth century is considered as a revival promoter of national traditions. In theoretical works he emphasized that he is not prejudiced against to the scientific and technical progress, however, he regretted that the new technology does not create an artistic value. In addition, especially radical his assessment was on Pavilion of London Great Exhibition of the Industry of All Nations in 1851 as a warm house for cucumbers, which has just a bigger frame. After the Great Exhibition of the Works of Industry of All Nations in London, England in the middle of the $19^{\text {th }}$ century (CieškaitèBredikienè, 2008), these industrial aesthetic phenomena spread almost all over Europe, including Lithuania, as a part of the Russian Empire (Figure 3) (http://www.miestai. net), North America (Dormer, 1993; Lees-Maffei \& Houze, 2010) and Japan. The idea of Industrial Revolution in the nineteenth century at the first time in the cultural history raised up the problem of consequences of the interaction between art, science, industry, and society (... "good societies produced good people and good people produced good design" (Hill, 2007)). Augustus Welby Northmore Pugin (1812-1852) was one of the most famous aesthetics and lifestyle promoters of a medieval epoch in the Victorian era. He idealized the harmony, order and spiritual stability of medieval society, and he saw the reflections of that in the junction of material environment and human harmony.

This problem is associated with the compatibility solutions of aesthetical, technical solutions and the needs of society (Jakaitis, 2013).

The railway bridge in Jonava (Figure 3) was built in 1914 by the project of Petras Vileišis and Anupras Vileišis. It is one of the examples from the period of the material environment modernism and the technical aesthetics, because of an industrial coup. Petras Vileišis wrote his biography on March 25, 1925 when he was a Minister of Transport and Communication of Republic of Lithuania, later on August 13; 17; 18, 1931 it was published in "Dienos naujienos" [Daily News] (Aničas, 1992). This bridge went through changeable socio-cultural and technological change periods. For example, when an army of Russian Empire retreated in 1915 the left pillar of the bridge was exploded. Later Germans rebuilt it. At the period of independent Lithuania in 1937 the upper parts of defence towers were exploded in order to adjust the orientation of defensive direction (Figure 4) - to the east, in the direction of Soviet Russia. In a period of World War II, by retreating of German army it was repeatedly partially destroyed.

The Soviet army finally destroyed the bridge in 1946 when exploding the spring ice drifts. On the place of old bridge later, in 1948, the new railway bridge of Jonava (Jonava Iron Bridge) was built. The location was approximately 20 meters further downstream towards Kaunas, remembering the old one only by survived support (Figure 5)

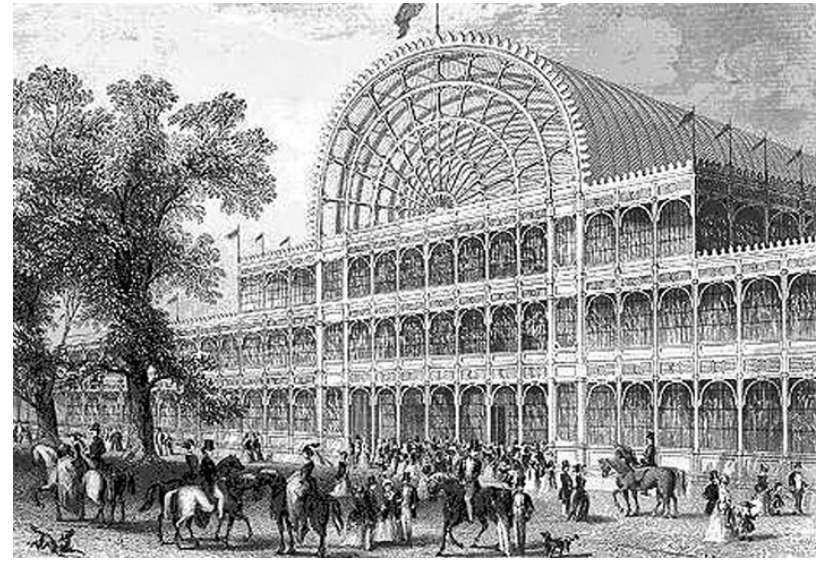

Figure 1. Paxton, J. 1851 Great Exhibition of the Industry of All Nations. The first industrial building object "Crystal Palace" was a technological masterpiece at that time. For design of pavilion at first, time was proposed a special modular system design (available from internet: https://www.miestai.net/forumas)

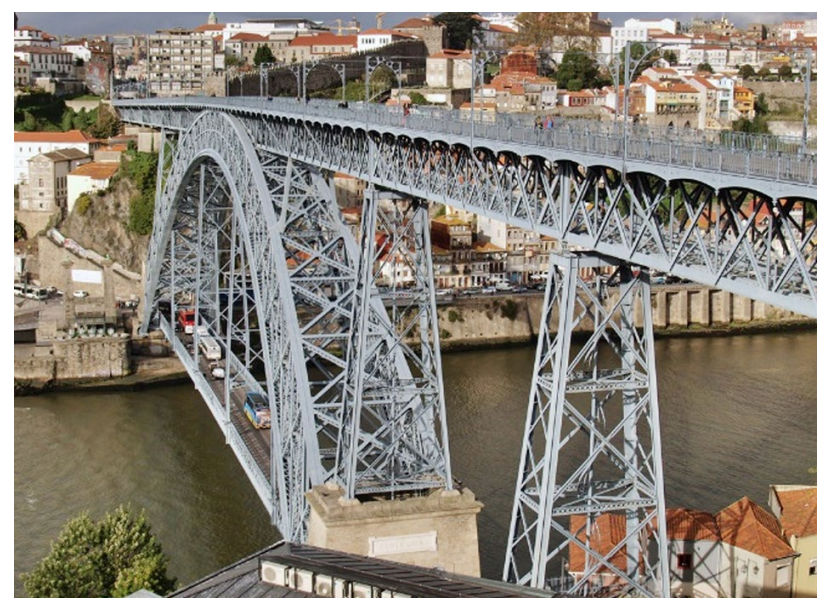

Figure 2. Léopold Valentin (the assistant of famous Paris Eiffel tower author Gustav Eiffel). 1886. Don Luis Bridge in Porto the first masterpiece in the nineteenth century which has become one of the symbols of the city. Arched, 72 meters high, twostory steel structures bridge, using for pedestrian, car and rail transport connections (J. Jakaitis photo)

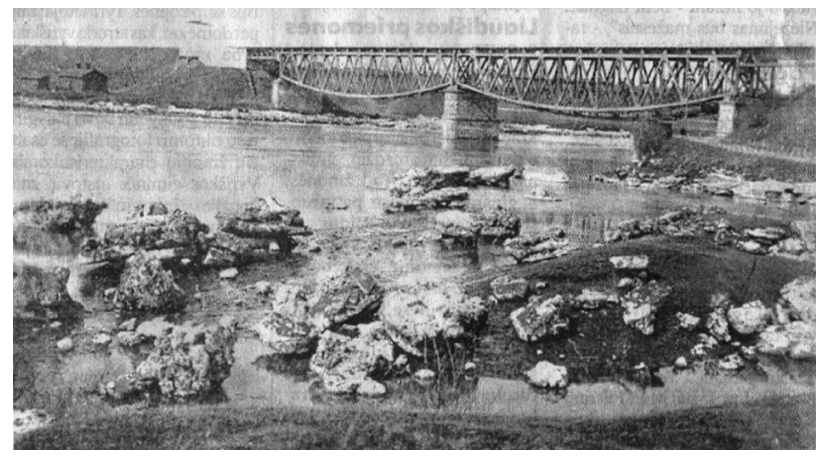

Figure 3. Petras and Anupras Vileišiai Jonava railway bridge designed in 1914 in the spirit of Industrial Revolution, built inspired by modernism (available from internet: https://www. miestai.net/forumas) 


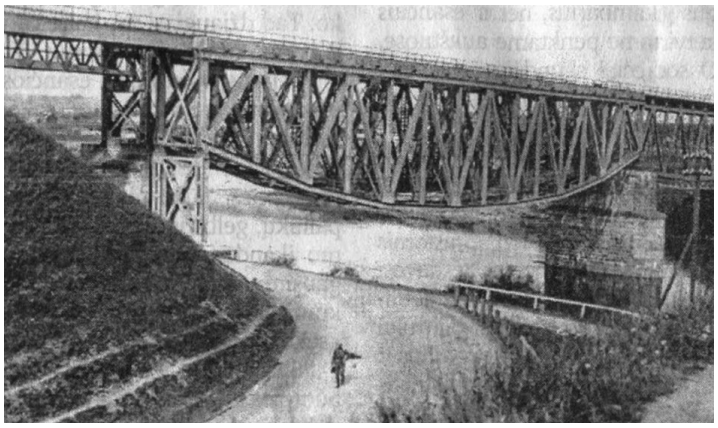

Figure 4. Jonava railway bridge restructured by Germans in 1941 (available from internet: https://www.miestai.net/forumas)

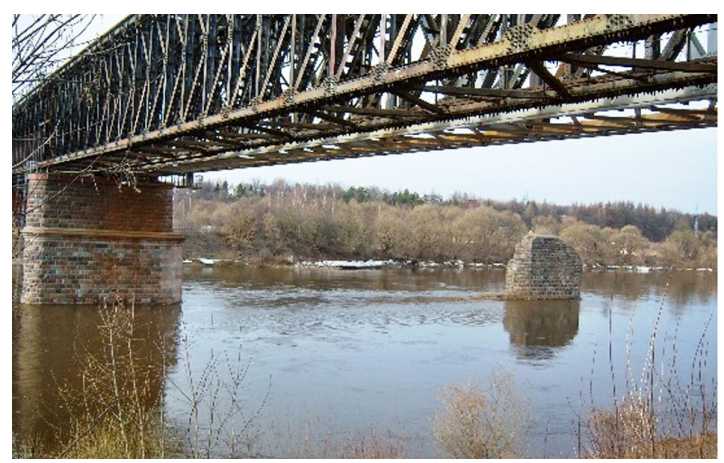

Figure 5. In the context of new railway bridge built in 1948 over the river Neris as a significant historical accent in the river Neris the old pier was left which represents historical memory of the old bridge (available from internet: https://www.miestai.net/ forumas)

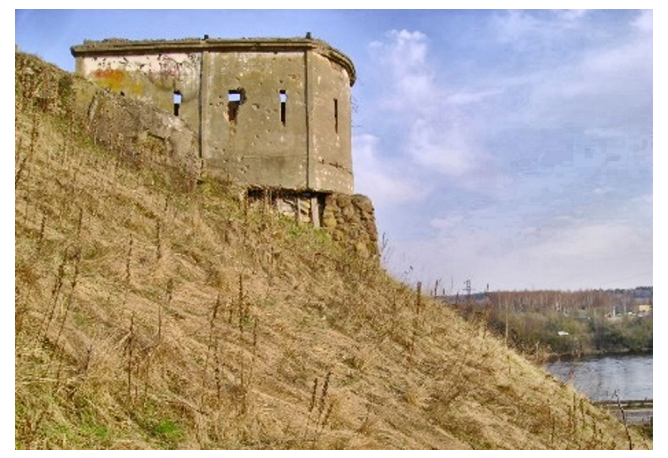

Figure 6. Old bridge defense towers (available from internet: https://www.miestai.net/forumas)

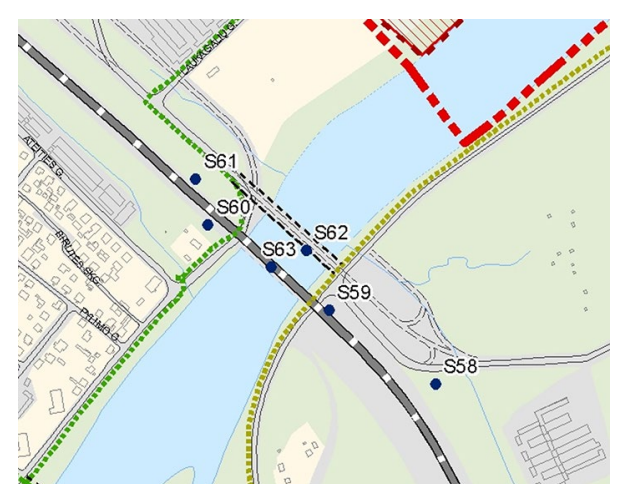

Figure 7. The passage of Jonava territory general plan drawing no. 5.1 (territories and zones of cultural heritage objects) situated in the river Neris. By the importance, the Iron Bridge distinguishes by a special construction, also by architectural solutions based on the spirit of the industrial coup, by landscape solutions characterized by integrity, by applied design solutions based on constructivism. The bridge consists of industrially manufactured iron constructions, which are supported by three brick-built pillars (two - on coasts of the river Neris and one pillar in the middle of the riverbed). A significant tag of historical memory of the Iron Bridge retains the abutment in the bed of river Neris (Figure 5).

Near to the railway bridge four concrete bunkers survived - shelters two of which built around 1914 and two in the inter-war period (Figure 6). They were intended for the defence of the bridge. The objects of this type to defend the bridge buildings in the inter-war period have been found only near to the two bridges in Lithuania. These objects being operated by "Lietuvos geležinkeliai", AB will influence further development of additional track provided on railway project "Rail Baltica". Inspection capabilities of the railway bridge and defence shelters 1, 2, 3, 4 are limited for the reason that they are inside the railways and their equipment protection zones. These and other objects are further investigated, taking into account all aspects. They can be included into the Register of Cultural Properties of Lithuania only in accordance with procedures of Cultural Heritage Protection Statutory of Lithuania.

Thus, the various aspects of the object, built in 1914, have been widely discussed during the inter-war period as the object of applied arts, developed in modernism spirit of material environment. Also as the prospect of important de facto objects for cultural heritage (Railway Bridge (S63)) and the defence shelters (S60, S61, S58, S59)) (Figure 7), they were discussed as an issues for preservation of the cultural identity area. Also they were discussed in terms of adaptability and the development of railway (Public Railway Infrastructure Network 2011-2012 Statement 2010), understanding the needs of the present (Jonava City Territory General Plan, 2010).

\section{Modern discourse of the problem}

In the first half of twentieth-century the modern art as an outcome of industrial applied aesthetics developed due to the different formation way of material environment. Industrial aesthetics spread in the art and crafts, came in architecture, civil engineering, was reflected in the design of material environment objects by providing the freedom to create without historical canons (Venturi, 1936). Industrial production, standards entrenchment based on logical thinking became as a basis for the engineering design and as a feature of modern society, and for the architects, engineers or designers as an everyday work tool.

The constructive peculiarities of steel bridges, the solutions for landscape architecture or for other objects of technical aesthetics urban areas or vintage design material environment are a common trend as a complex analysis in terms of both developing and developed countries in 
respect of cultural heritage objects of sense. The results of applicability study for modern needs for such objects as Jonava railway bridge over the river Neris become benchmarking bases as a technical, economic, aesthetic harmony solution of the landscape also as applied design objects. In order to address the applied and functional problems of regional integrity or national security, such as a development of new trans-European network of double-track offshoot over Jonava in the Rail Baltica section (Rail Baltica, 2011) or development of railway buildings in trans-European transport network (TEN-T) IXB and in IXD Crete corridors.

World scientists agree that separate sectors of infrastructure and its development undoubtedly have an impact on national and regional economic and socio-cultural attractiveness of the country. However, the topic of modern applicability of the infrastructure objects is low discussed and especially the adaptability of heritage objects for the needs of contemporary society, in relation to innovative solutions. Especially low is an exploration of the problems of physical security of engineering infrastructure, the optimization of technical and aesthetic requirements, which is relevant for both Lithuania and for the development of infrastructure in EU countries.

Bridge test is a technique to evaluate the situation of the building (Sousa et al., 2016). Bridge tests are organized in the following cases (Bačinskas et al., 2013):

- to check the design and construction ideas and assumptions, especially when the new materials, structures, technologies are used;

- lack of information on the elements geometry, design schemes, materials etc., does not allow to reliably use analytical methods for condition assessment;

- very damaged structures, there are a lot serious defects and damages of material, when integrated assessment of building functionality in analytic way is impossible;

- to check the efficiency of construction, repair and reconstruction work;

- before moving on the bridge heavy or oversized loads vehicles.

Bridge testing is a reliable way to assess the technical condition of the bridge (Bačinskas, Turla, Kilikevičius, Ragauskas, \& Jurevičius, 2014; Skeivalas, Jurevičius, Kilikevičius, \& Turla, 2015) because the test results show the actual behaviour of the building under static or dynamic loading. The tests evaluate the factors that neither the design nor the construction process of the bridge can take in to account. These factors are: the influence of trackway and ballast to the behaviour of the overlay, small eccentricities of the efforts, the pressure to the elements of supporting bearings, the surrounding of the junctions and bonds, spatial work of the elements and etc. Systematically collecting the data of the test of various bridges and the experience, there are an improvement of the bridge calculation and analysis methods, regulatory documents, new ideas for the bridges and technologies (Kamaitis, 1995).
These issues in combination with probabilistic techniques (Zambon et al., 2017) are the key factors for improvement of analysis and design methods as well as construction technologies and maintenance strategies for the future bridges.

Railway bridges suffer very high dynamic loads (Bačinskas, Kamaitis, \& Kilikevičius, 2013; Camara, Nguyen, Ruiz-Teran, \& Stafford, 2014; Shiling, Yongle, Yulong, Xin, \& Shizhong, 2016). On the other hand, the traffic runs on the clearly fixed road. These aspects often inspire the phenomenon of structural fatigue. The bridge behaviour also depends not only on the features of bridge structures and support but also on the trackways fastening on the bridge (Zhai, Cai, \& Wang, 2004; Lin \& Yang, 2005).

A group of researchers found (Kossakowski, 2013; Xia \& Zhang, 2005; Zhai et al., 2013) that due to the railway trains the bridge undergoes considerable vibrations, particularly in the horizontal transverse direction. Therefore, it was decided to experimentally determine the main dynamic characteristics of the bridge and check their compliance with requirements of the regulatory documents SNiP (SNiP 2.05.03-84) and LST EN 1991-2:2004/ $A C: 2010$. According to the authors' knowledge, field dynamic tests of the bridge under consideration were carried out for the first time.

The main goal of the research - to perform verified dynamic testing for continuous truss steel railway bridge over the river Neris in Jonava and to obtain information about the bridge dynamic parameters (resonance and forced oscillation frequencies and shapes, forced oscillation acceleration amplitudes, dynamic displacements).

\section{Dynamic tests: measurement equipment and its layout, measurement methodology}

During the dynamic tests, the vibrations of the bridge caused by passing of different trains (Figure 8) on different speeds as well as by the impact loads were measured. The layout of measuring devices is presented in Figure 9.

On the way the vertical (sensors marked with the letter "v") and horizontal (sensors marked with the letter " $\mathrm{h}$ ") accelerations of vibrations and displacements were measured. Measurements were done in sixteen points of the lower and upper chord of steel truss. Measurements of the support's vibrations were done at a single point in the upper part of the support, in the section between the supporting bearings. The obtained results were used to establish the basic dynamic indicators: the frequency and shapes of vibrations, the acceleration of vibrations and logarithmic damping decrement, the dynamic displacements. For the measurements the Brüel and Kjær LAN XI dynamic test system was used (Figure 10a). For the measurement of acceleration and dynamic displacement the low-frequency seismic piezoelectric accelerometers were used (in Figures 10b and 10c). During the measurement the received signals were processed by applying Brüel and Kjær software. To remove the noise the signal filtering was used in accordance with the recommendations of 


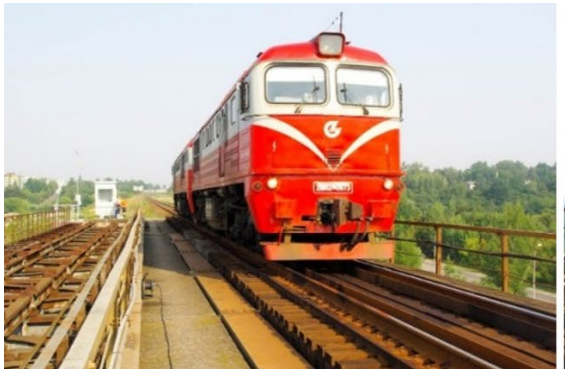

Locomotive 2M62

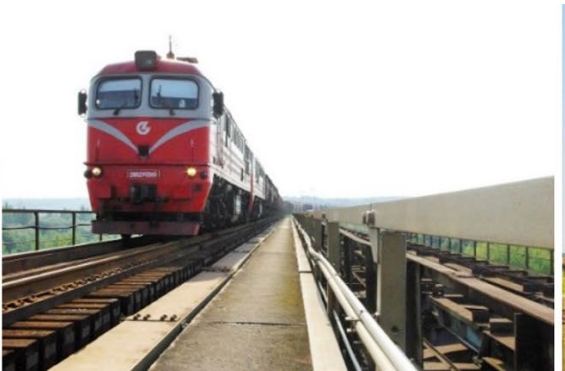

Passenger train

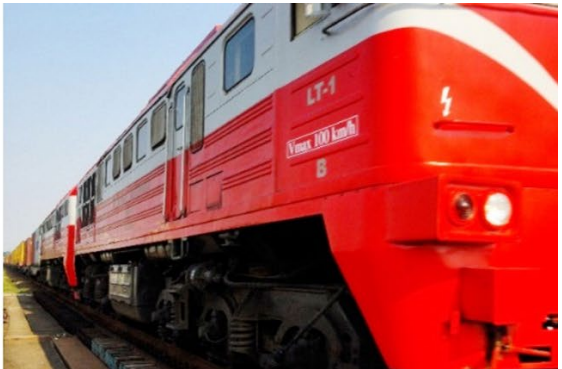

Freight train

Figure 8. Excitation of bridge oscillations exposure to different operational loads

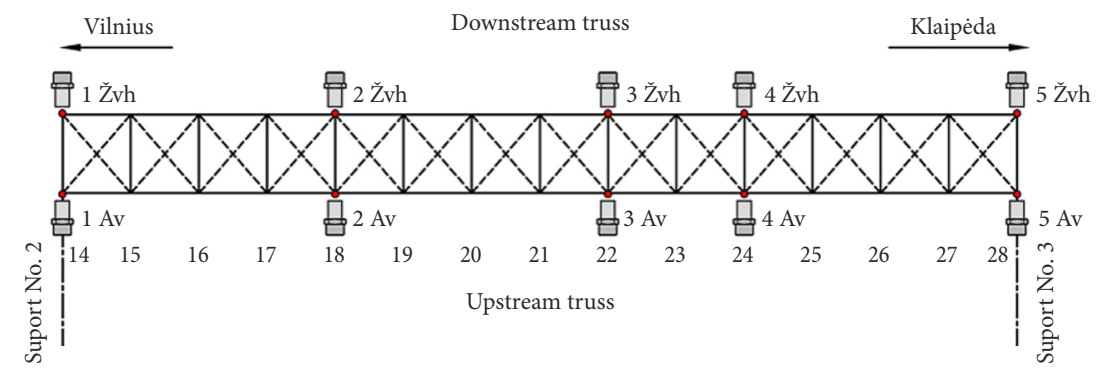

Figure 9. Layout of the measurement devices of dynamic parameters of the bridge overlays
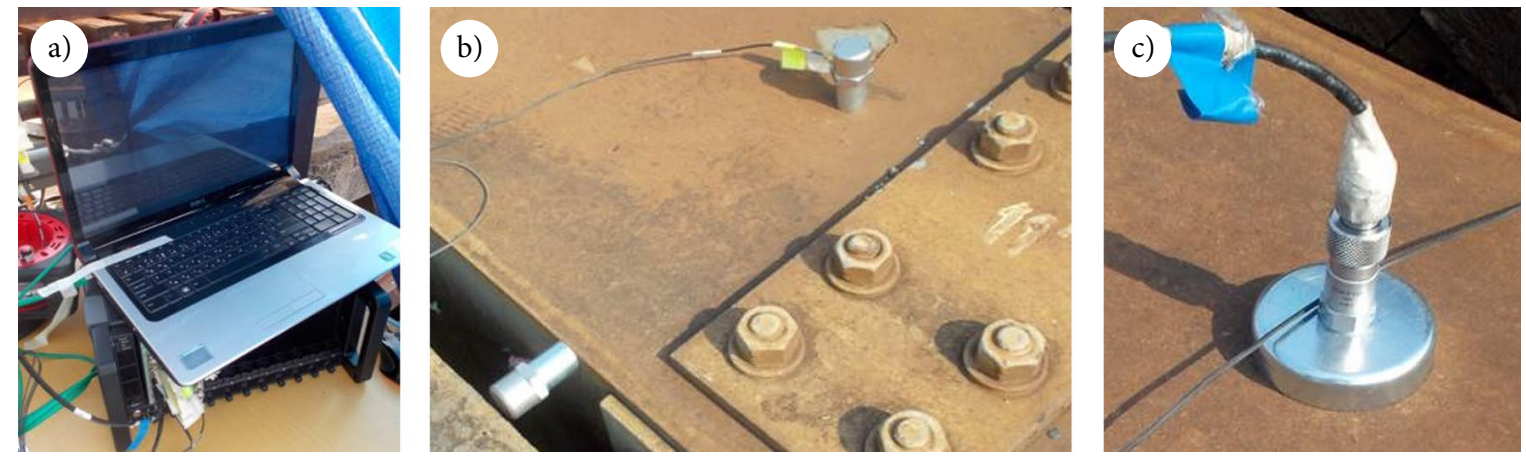

Figure 10. Brüel \& Kjær dynamic oscillations measurement system: a - the piezoceramic low frequency; b - and less sensitive; $c$ - converters for measurement for vertical and horizontal oscillations

the source (LST-EN 1990:2004/A1:2006). It recommends certainly regard the frequencies which are higher than a) $30 \mathrm{~Hz}$; b) 1.5 times the frequency of the fundamental mode of vibration of the member being considered; c) the frequency of the third mode of vibration of the member. During the running of trains behavior of bridge superstructure and supporting bearings has been observed.

\section{The results of dynamic tests}

The free vertical and horizontal vibration parameters of the bridge steel superstructure are defined. The highest amplitudes and damping ratios of free vibrations induced by both impulse excitation (shock loads) and locomotive 2M62 have been indicated. After the stimulation of vibration, the bridge deck is usually vibrating in several oscillation modes simultaneously. On spectrograms of resonance vertical and torsional oscillations of the bridge deck four modes were identified. Additionally, one horizontal vibration mode was obtained (Table 1). Typical examples for free vibration spectrum of deck are given in Figure 11. In the spectrum of horizontal and torsional vibrations, the first and the second modes are very clear. The corresponding frequencies are $1.7 \mathrm{~Hz}$ and $3.2 \mathrm{~Hz}$, respectively. In the spectrum of vertical vibrations, the clearest and most important is the first mode with the frequency of $4.2 \mathrm{~Hz}$. Other modes are more unobtrusive; moreover, they are very similar to nonresonance modes, and it is quite hard to accurately identify them.

The first five mode shapes obtained after experimental modal analysis are presented in Figure 12. In Table 2 the main experimental modal analysis data are given: frequency values of modes and obtained damping coefficients for each mode. Vibration damping is an important dynamic parameter of structures, especially when the train speeds 
Table 1. Overlay shape and frequency of oscillations

\begin{tabular}{|c|c|c|l|}
\hline \multirow{2}{*}{ Oscillation shape } & \multicolumn{2}{|c|}{} & \multicolumn{2}{|c|}{ Oscillation shape form } \\
\cline { 2 - 3 } & $\bar{X}, \mathrm{~Hz}$ & $\sigma_{x}, \mathrm{~Hz}$ & \\
\hline 1 & 1.7 & 0.014 & horizontal bending half-wave \\
2 & 3.2 & 0.090 & torsional half-wave \\
3 & 4.2 & 0.020 & vertical bending half-wave \\
4 & 8.1 & 0.470 & torsional two half-waves \\
5 & 10.4 & 0.650 & vertical bending two half-waves \\
\hline
\end{tabular}
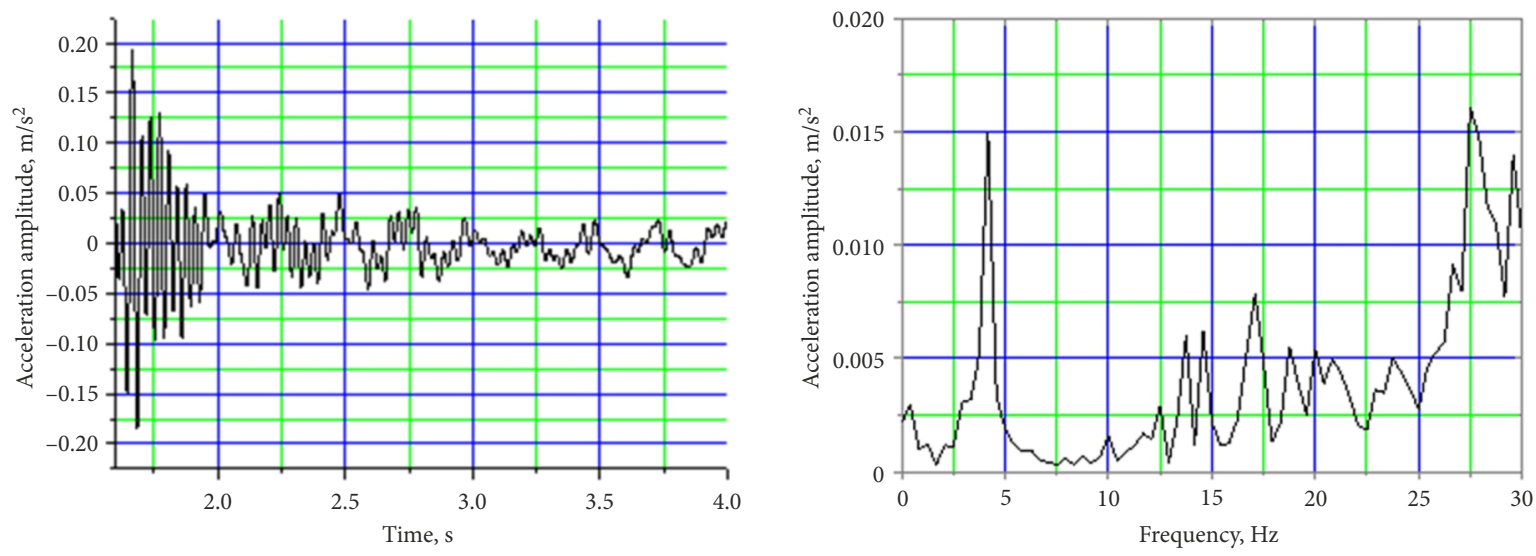

Free vertical vibrations (peak $4.16 \mathrm{~Hz}$ )
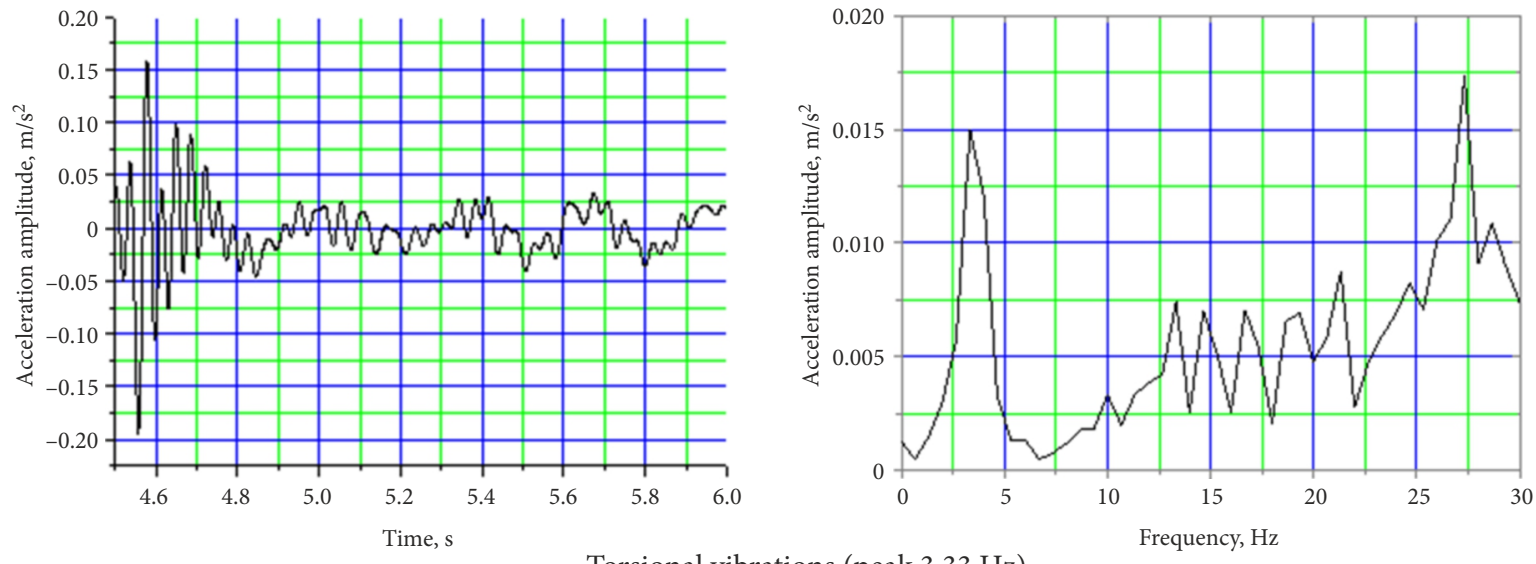

Torsional vibrations (peak $3.33 \mathrm{~Hz}$ )
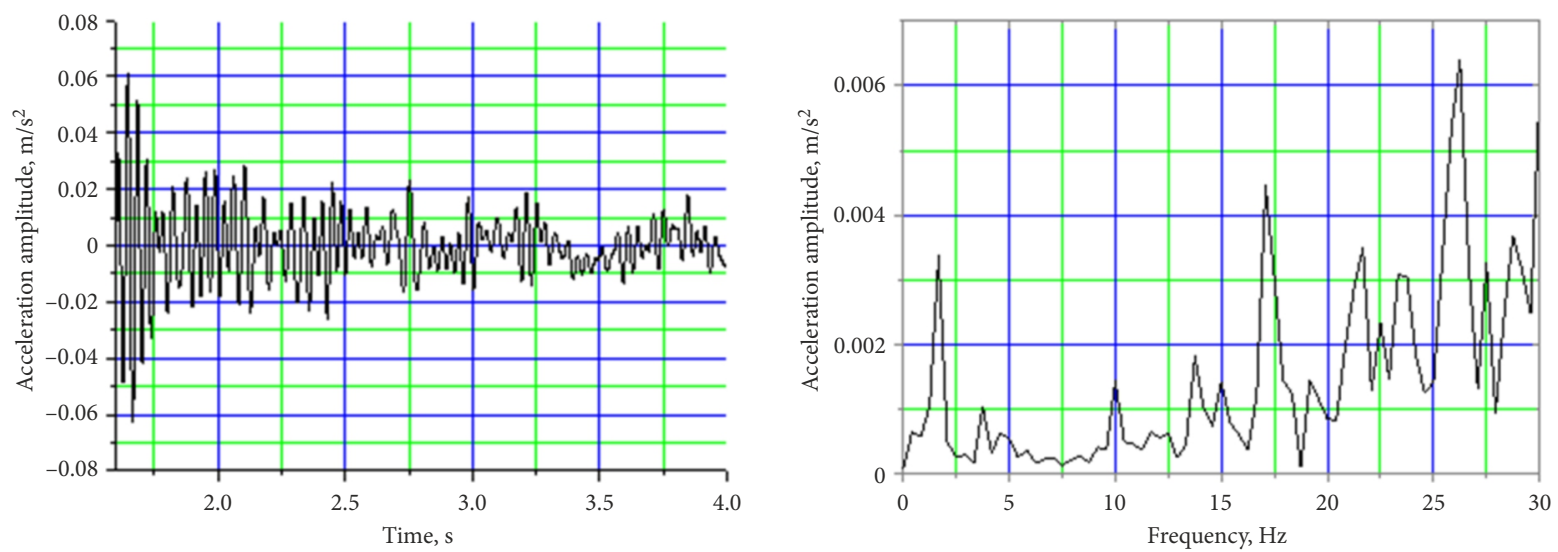

Horizontal vibrations (peak $1.66 \mathrm{~Hz}$ )

Figure 11. The vibrations and the frequency spectrums for the equatorial section of bridge deck 


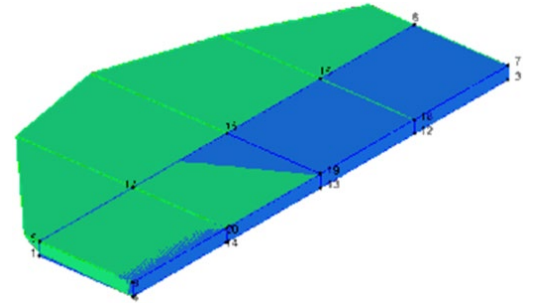

Horizontal bending a half-wave

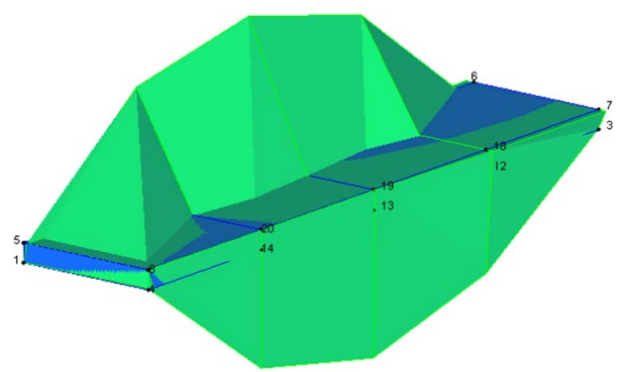

Vertical torsion a half-wave

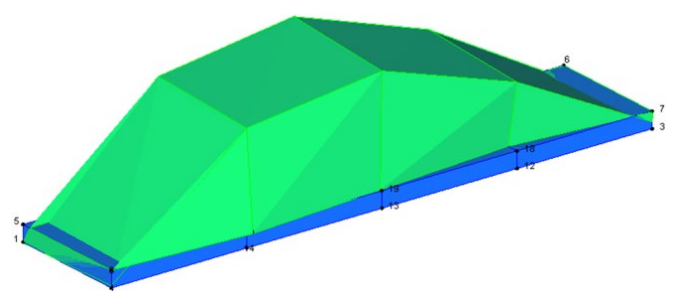

Vertical bending a half-wave

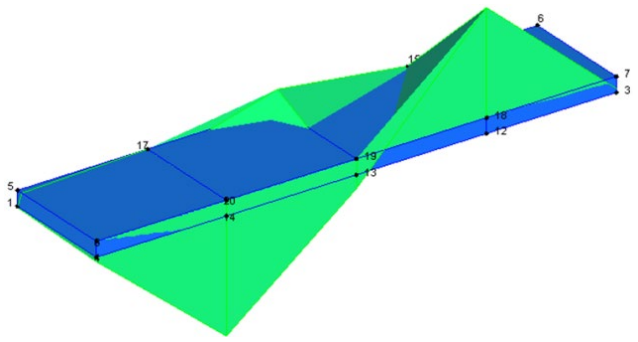

Vertical torsion two half-waves

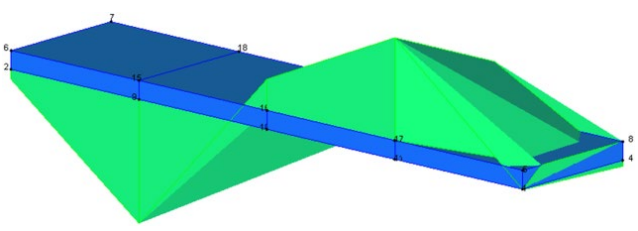

Vertical bending two half-waves

Figure 12. Mode shapes obtained during experimental modal analysis

correspond to resonant load. Lithuanian Standard (LSTEN 1990:2004/A1:2006) regulates the critical value (lower limit) of the vibration damping which value for steel bridges is 0.5 . Thus, the Lithuanian standard gives conservative (cautious) values for vibration damping parameters. As shown in Table 2, for lower mode s the damping coefficients are close to the threshold value provided by standard.
Table 2. Mode shapes, frequencies and damping coefficients of free vibrations of bridge deck

\begin{tabular}{|c|c|c|}
\hline Mode No. & Frequency, $\mathrm{Hz}$ & Damping coefficient, \% \\
\hline 1 & 1.71 & 3.890 \\
\hline 2 & 3.20 & 2.170 \\
\hline 3 & 4.21 & 1.510 \\
\hline 4 & 8.14 & 0.475 \\
\hline 4 & 10.38 & 0.656 \\
\hline
\end{tabular}

The bridge is designed according to SNiP code, which govern the oscillation period of the first shape of horizontal transverse vibration for steel and steel-concrete composite railway bridge decks. It shall be less than $0.01 \mathrm{~L}$ (where $L$ - the length of the span of deck, $\mathrm{m}$ ) and must be not higher than 1.5 seconds. For the current bridge, the period of the first horizontal oscillation mode is $T=1 / 1.7$ $1 \mathrm{~Hz}=0.585 \mathrm{~s}<0.01 .75=0.75 \mathrm{~s}<1.5 \mathrm{~s}$. Thus, the requirements of SNiP norms are met. Lithuanian Standard (LST EN 1991-2:2004/AC:2010) regulates the upper and lower frequency limits of free oscillations $n_{0}$ of the first shape for bridge decks, depending on the span length $L$.

The upper limit Eq. (1):

$$
n_{0}=94.76 L^{-0,748}=94.76 \cdot 75^{-0,748}=3.75 \mathrm{~Hz} .
$$

The lower limit Eq. (2):

$$
n_{0}=\frac{80}{L}=\frac{80}{75}=1.07 \mathrm{~Hz} \text {. }
$$

The first frequencies of free vertical vibrations fall into specified limits $\left(1.07<n_{0}=1.71<3.75\right)$, while the train speeds $v<200 \mathrm{~km} / \mathrm{h}$, the dynamic analysis for bridge deck is not necessary. Standard LST-EN 1990:2004/A1:2007 Eurocode - Basis of Structural Design Eurocode 1 provides the requirement for the lower limit $\left(n_{h 0} \geq 1.2 \mathrm{~Hz}\right)$ of horizontal free vibrations of the first shape for the decks of railway bridges. This requirement is are also met, here $n_{h 0 \mathrm{I}}=1.71 \mathrm{~Hz} \geq 1.2 \mathrm{~Hz}$.

The passing trains near and on the bridge decks always causes the vertical and horizontal (transverse) vibrations of the bridge structures. Vertical oscillations essentially depend on the mass and speed of the train. The train eccentrically running (regarding the longitudinal axis of the bridge) and swinging causes transverse oscillations of the bridge. The vertical and horizontal excitation forces induce spatial torsional vibrations of the bridge. During the test and approaching trains to the bridge the oscillations are transmitted through the rails and the ground, thus vibrations of increased amplitude appear on the deck that reach the maximum values when the trains drives on the deck (Figure 13). It should be noted that isolated high amplitudes of the accelerations are discernible in some vibrograms. It is supposed that they are caused by short beats of the wheels to the rail joints, as well as defects of rails and wheels. 

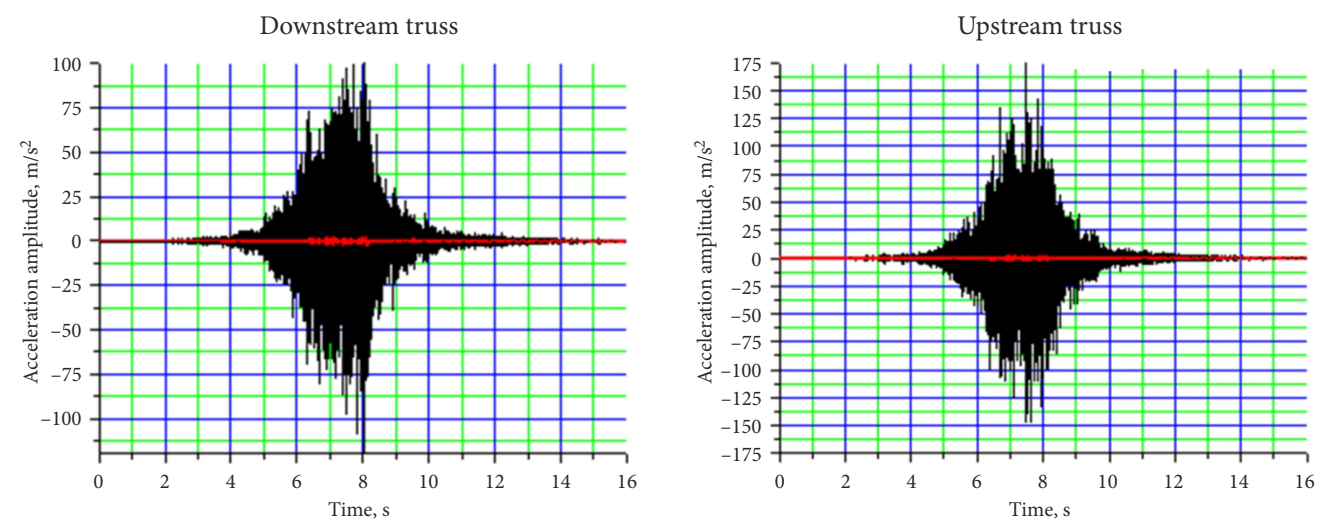

- D - $30 \mathrm{~Hz}$ low pass filter on CoID

- $\mathrm{H} \quad 30 \mathrm{~Hz}$ low pass filter on $\mathrm{CoIH}$

Oscillations induced by the locomotive 2M62 (a red line - filtered oscillations above $30 \mathrm{~Hz}$, a black line - unfiltered)
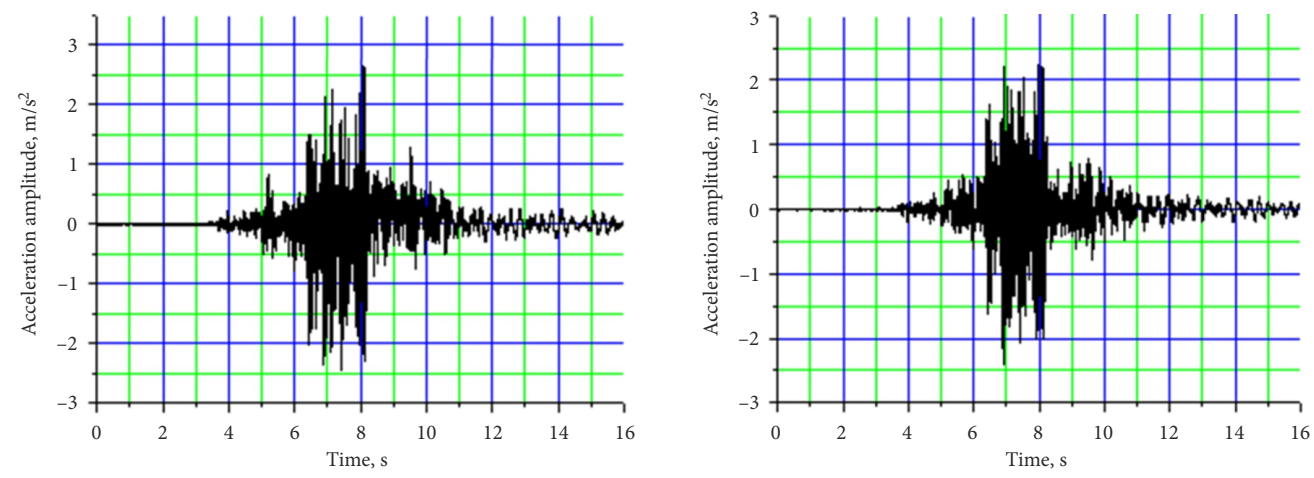

Oscillations induced by the locomotive 2M62 (filtered oscillations above $30 \mathrm{~Hz}$ )
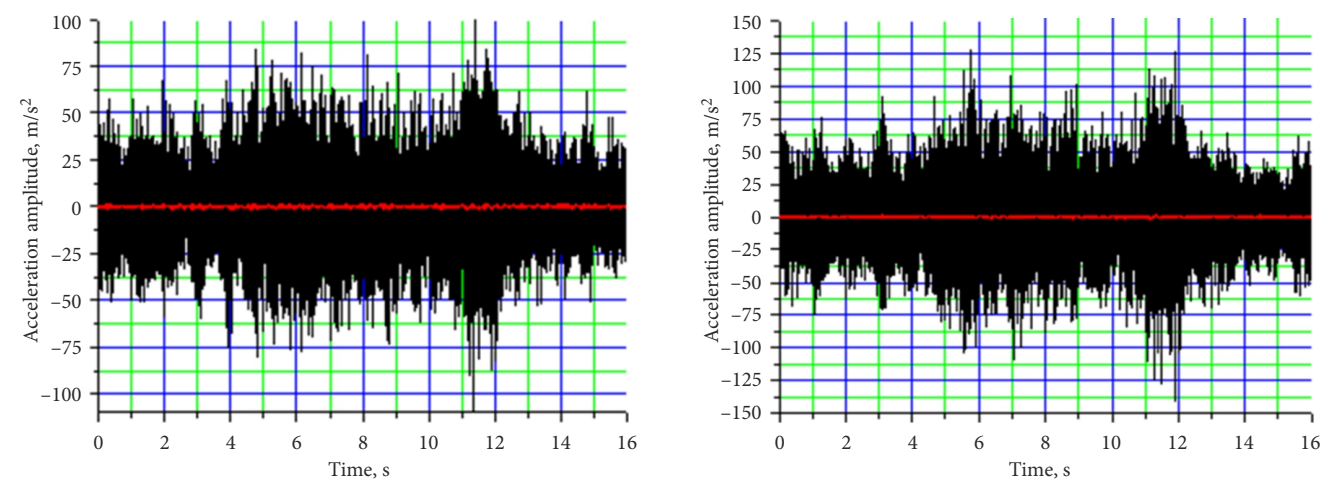

- $\mathrm{P} \quad-30 \mathrm{~Hz}$ low pass filter on CoIP

- $\mathrm{T}-30 \mathrm{~Hz}$ low pass filter on CoIT

oscillations induced by freight train 1 and 2 (red line - filtered oscillations above $30 \mathrm{~Hz}$, a black line - unfiltered)
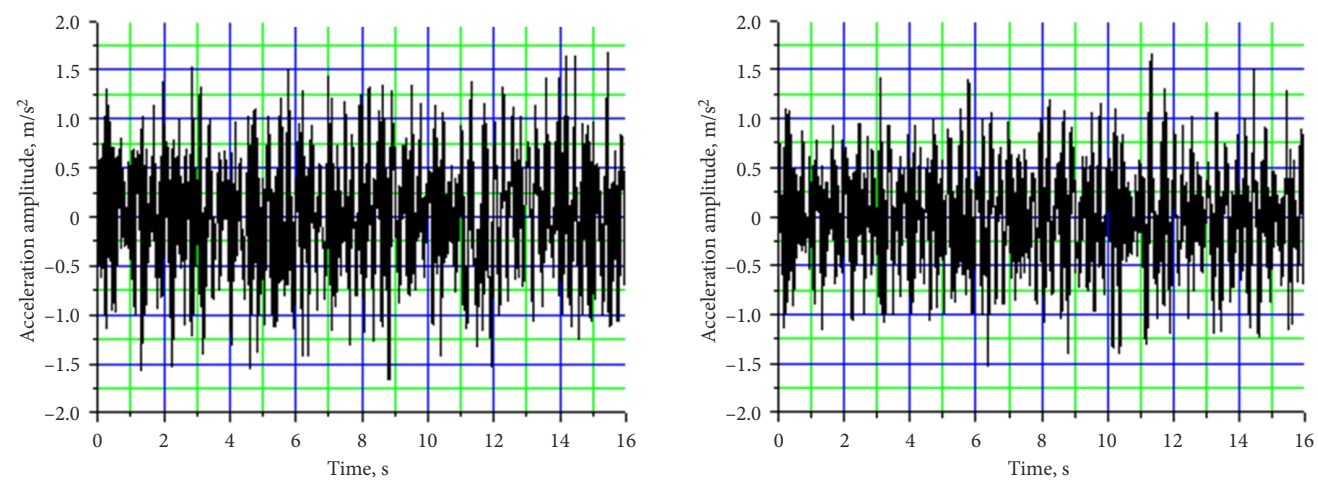

Oscillations induced by freight train 1 and 2 (filtered oscillations above $30 \mathrm{~Hz}$ )

Figure 13. Vertical oscillations of downstream and upstream truss 


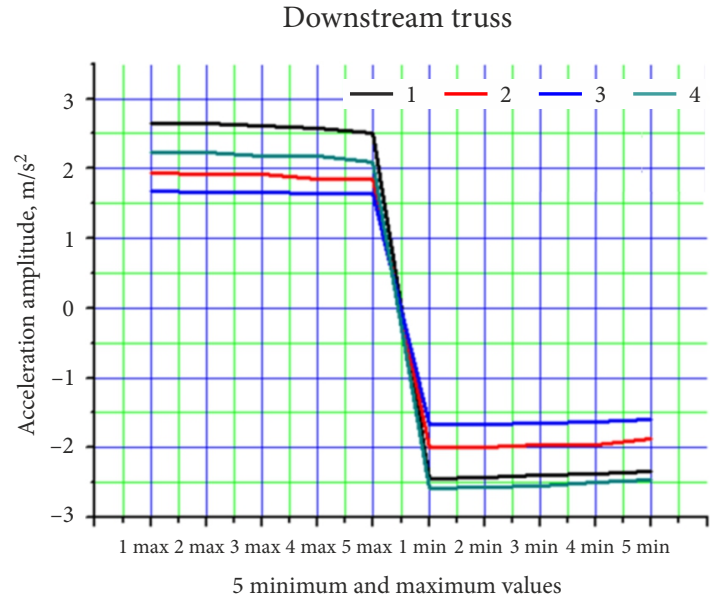

Acceleration amplitudes in vertical direction

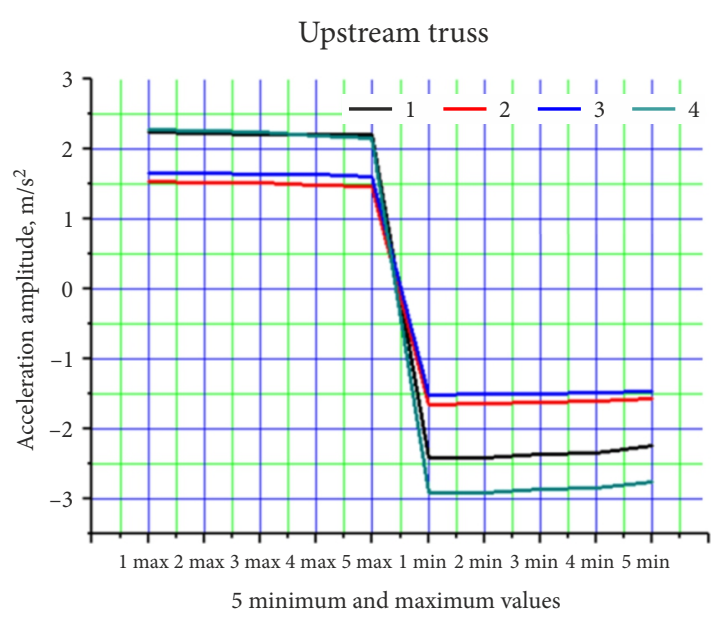

Acceleration amplitudes in vertical direction

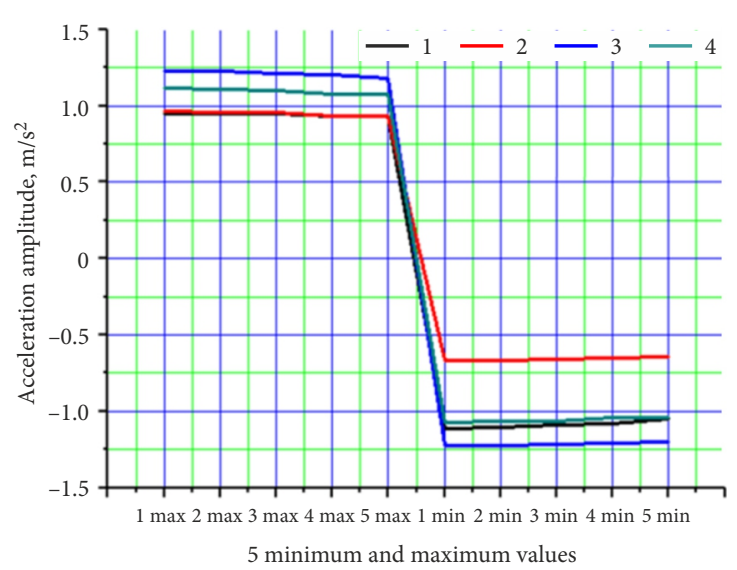

Acceleration amplitudes in horizontal direction

Figure 14. The dependency of acceleration amplitudes values to various types of passed trains ( 1 - locomotive 2M62;

2 - passenger train; 3 - 1-st freight train; 4 - 2-nd freight train)
Maximum values of accelerations of vertical and horizontal forced vibrations are important parameter for bridge decks. As shown in Figure 13, after filtration of acceleration values higher than $30 \mathrm{~Hz}$ the obtained results are: by running of an isolated locomotive $2 \mathrm{M} 62$ the maximum amplitude of acceleration is $a_{\max }=2.65 \mathrm{~m} / \mathrm{s}^{2}$ in vertical oscillations of downstream truss, and $a_{\max }=$ $2.24 \mathrm{~m} / \mathrm{s}^{2}$ in vertical oscillations of the upstream truss. The maximum amplitude of acceleration $a_{\max }=0.95 \mathrm{~m} /$ $\mathrm{s}^{2}$ in horizontal oscillation of downstream truss was induced by the impact of $2 \mathrm{M} 62$. When the passengers train passes, the maximum amplitude of acceleration is $a_{\max }=$ $1.93 \mathrm{~m} / \mathrm{s}^{2}$ in vertical oscillation of downstream truss, and $a_{\max }=1.53 \mathrm{~m} / \mathrm{s}^{2}$ for the upstream truss. Accordingly, the amplitude of horizontal oscillations is $a_{\max }=0.96 \mathrm{~m} / \mathrm{s}^{2}$ for downstream truss. The amplitude of vertical vibrations induced by the freight train is $a_{\max }=2.23 \mathrm{~m} / \mathrm{s}^{2}$ for downstream truss and $a_{\max }=2.27 \mathrm{~m} / \mathrm{s}^{2}$. For the downstream truss the amplitude of horizontal oscillations due to the same effects is $a_{\max }=1.11 \mathrm{~m} / \mathrm{s}^{2}$. The obtained results show that the vertical accelerations amplitudes for both trusses are very similar. They are slightly higher for the downstream truss. The differences in horizontal oscillations were not identified.

Taking into account the traffic safety criteria, the standard LST-EN 1990:2004/A1:2006 regulates such threshold values of maximum accelerations for ballastless railway bridges decks: for vertical oscillations $a_{\max } \leq 5 \mathrm{~m} / \mathrm{s}^{2}$. Thus, the amplitudes of vertical accelerations do not exceed the requirements of the currently valid Lithuanian design code. According to the standard (LST-EN 1990:2004/ A1:2006), it is necessary to take into account the passengers comfort criteria when the train passes over the bridge. That standard determines the vertical acceleration $b_{v}$ requirements in the wagon. However, the recent parameters can be set only after dynamic analysis of vehiclebridge interaction.

Figure 14 presents variation of the acceleration amplitudes of forced vibrations caused by different trains. Figure 14a shows five maximum and minimum values of the vertical accelerations, while, Figure $14 \mathrm{~b}$ shows five maximum and minimum values of the horizontal accelerations. The maximum amplitudes are excited by the freight train and isolated locomotive.

Vertical and horizontal vibrations of the support in the longitudinal direction of the bridge were recorded at the different level of loads. The results are presented in Figure 15. From the vibrograms, we can see that due to operational load, the absolute values of the vertical and maximum amplitude of acceleration in horizontal longitudinal direction increase up to 50 times as compared to a situation when the support is not affected by the train load (in the paper relatively called as a calm condition). 

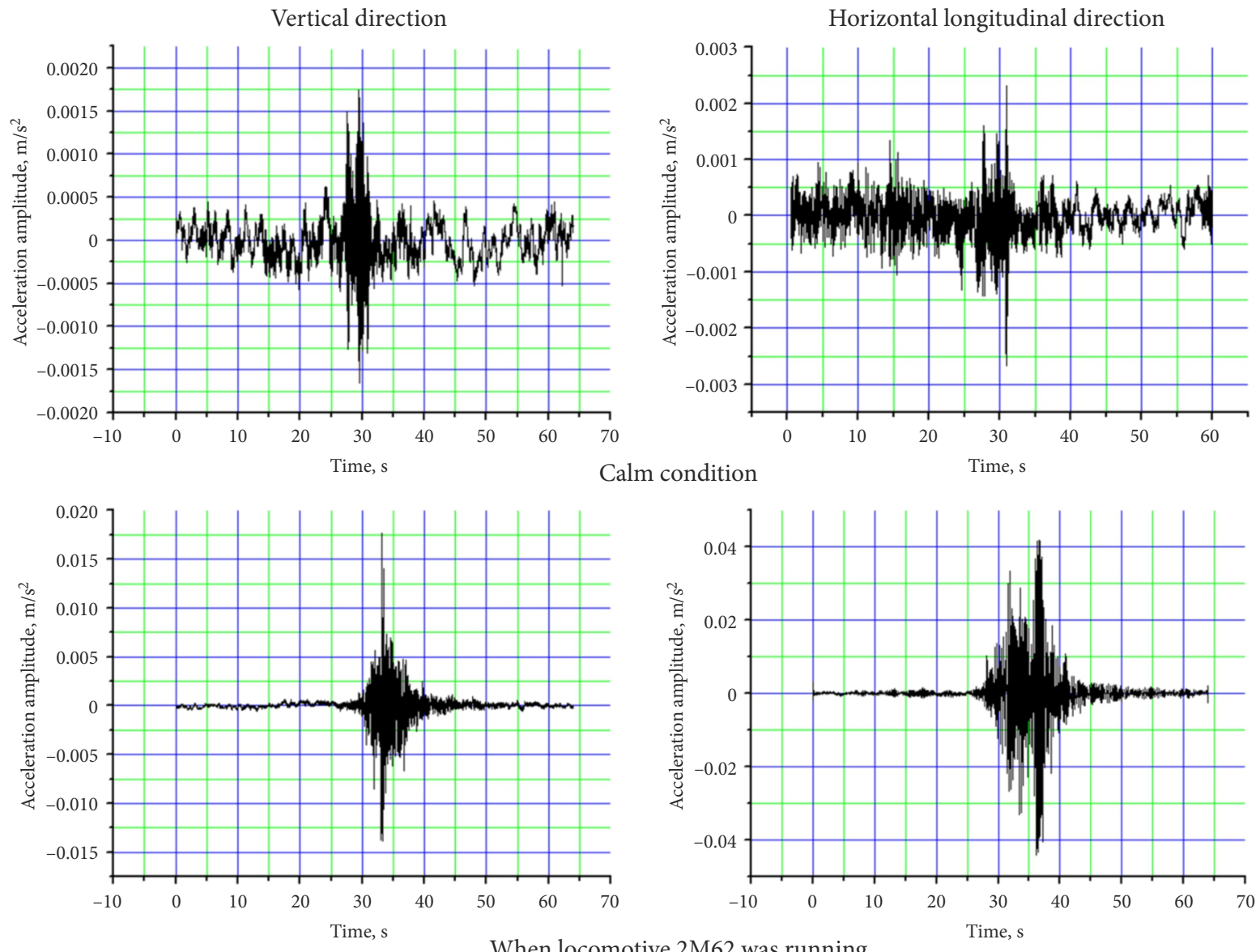

When locomotive 2M62 was running
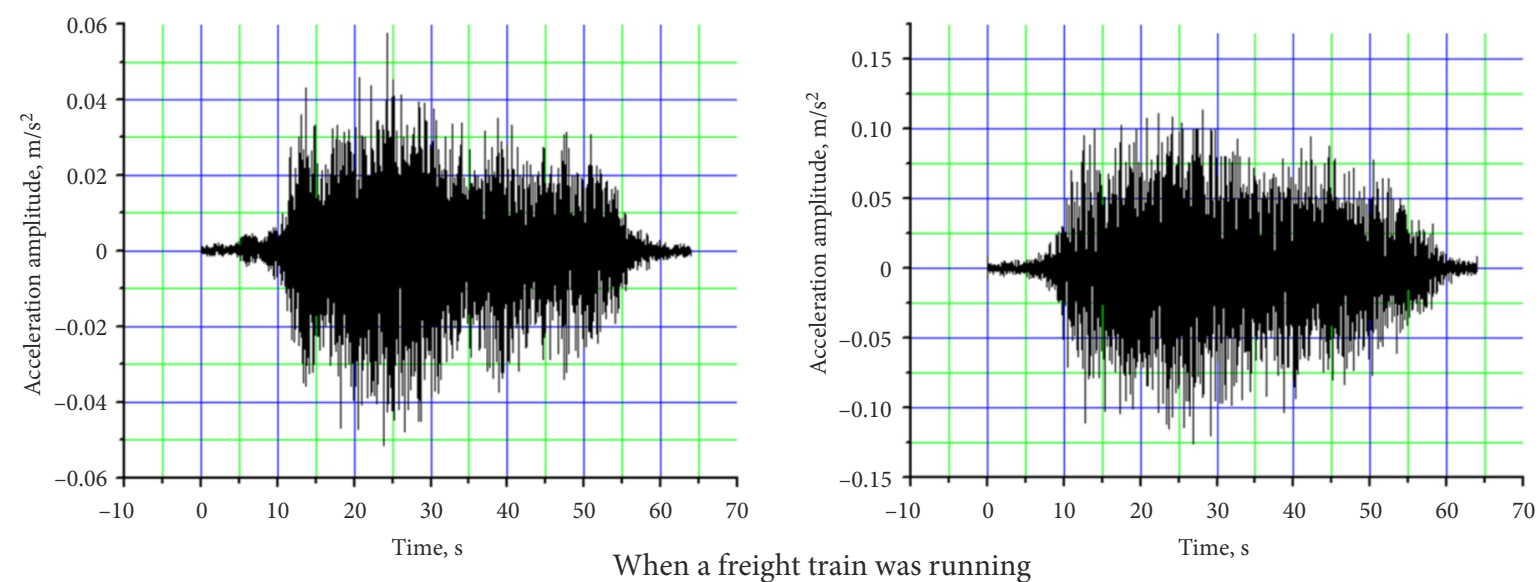

Figure 15. Vertical and longitudinal oscillations of support 2 (oscillations filtered over $30 \mathrm{~Hz}$ )

Table 3. Acceleration amplitudes of vertical of longitudinal oscillations in support 2

\begin{tabular}{|l|l|c|c|}
\hline \multirow{2}{*}{ Excitation type } & \multirow{2}{*}{ Oscillations direction } & \multicolumn{2}{c|}{ Acceleration amplitude, $\mathrm{m} / \mathrm{s}^{2}$} \\
\cline { 3 - 4 } & & $\min$ & $\max$ \\
\hline \multirow{2}{*}{ Calm condition } & vertical & -0.00166 & 0.00174 \\
\cline { 2 - 4 } & horizontal longitudinal & -0.00260 & 0.00232 \\
\hline \multirow{2}{*}{ Locomotive } & vertical & -0.01388 & 0.0177 \\
\cline { 2 - 4 } & horizontal longitudinal & -0.04417 & 0.04177 \\
\hline \multirow{2}{*}{ Freight train } & vertical & -0.05144 & 0.05759 \\
\cline { 2 - 4 } & horizontal longitudinal & -0.12568 & 0.11297 \\
\hline
\end{tabular}


However, in the case of intensive excitation of the deck, when the heavy freight train is passing over the bridge, the vibration level of the supports remains low. The maximum amplitudes of acceleration reach only: for vertical oscillation $-0.058 \mathrm{~m} / \mathrm{s}^{2}$, for horizontal oscillation $-0.126 \mathrm{~m} / \mathrm{s}^{2}$. Detailed values of the minimum (negative) and the maximum (positive) acceleration are given in Table 3 .

\section{Dynamic displacements}

When the trains are passing through the bridges, the vertical and horizontal (lateral) displacements of the decks appear (Figure 16), whose values depend on the speed. As speed increases, the dynamic displacements increase as well. It is known that the dependence of both vertical and transverse displacement from the speed can be nonlinear. Therefore, in the present study there are no possibilities to identify the displacements of the bridge deck subjected the action of the train passing the bridge at design speed. The numerical displacements values of the bridge deck are given in Table 4 . Figure 16 and Table 4 show that in many

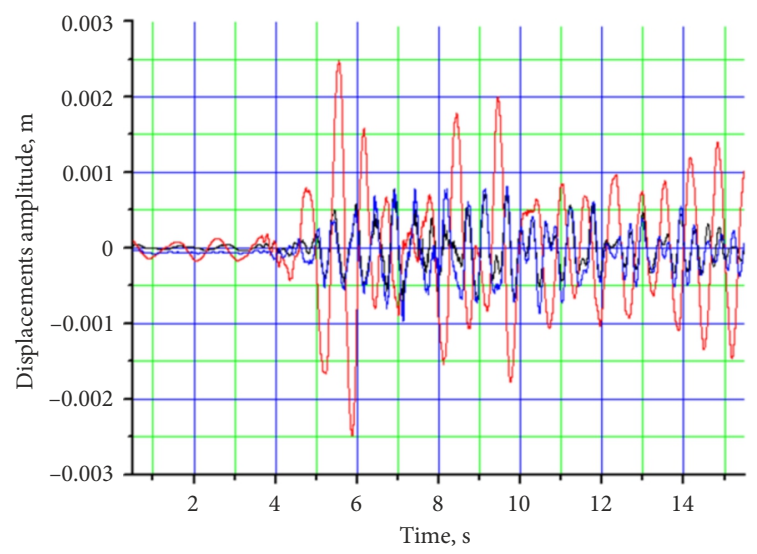

Locomotive 2M62

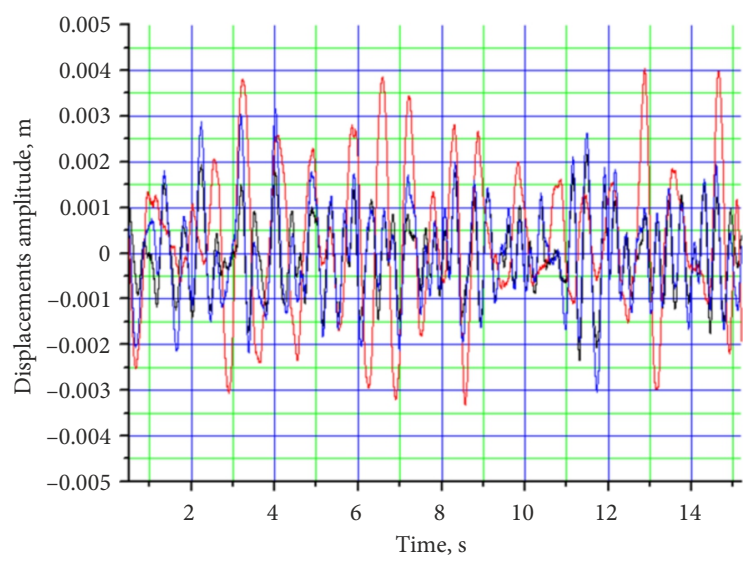

The freight train 1 cases the vertical dynamic displacements of the upstream truss are higher than the displacements of the downstream truss. This is the influence of the road axis eccentricity into the bridge axis (the road axis is shifted toward the upstream truss). The maximum vertical dynamic displacement is $3.06 \mathrm{~mm}$. This displacement can be used to determine the dynamic coefficient of the deck.

Table 4. Dynamic displacements $(\mathrm{mm})$ of the bridge deck

\begin{tabular}{|l|c|c|c|}
\hline \multirow{2}{*}{ Operating load } & \multicolumn{2}{|c|}{ Vertical displacement } & $\begin{array}{c}\text { Horizontal } \\
\text { displacement }\end{array}$ \\
\cline { 2 - 4 } & $\begin{array}{c}\text { Downstream } \\
\text { truss }\end{array}$ & $\begin{array}{c}\text { Upstream } \\
\text { truss }\end{array}$ & $\begin{array}{c}\text { Downstream } \\
\text { truss }\end{array}$ \\
\hline 2M62 & 0.75 & 0.90 & 2.36 \\
\hline Passenger train & 0.42 & 0.64 & 3.00 \\
\hline A freight train 1 & 2.34 & 3.06 & 3.28 \\
\hline A freight train 2 & 1.87 & 1.54 & 3.00 \\
\hline
\end{tabular}

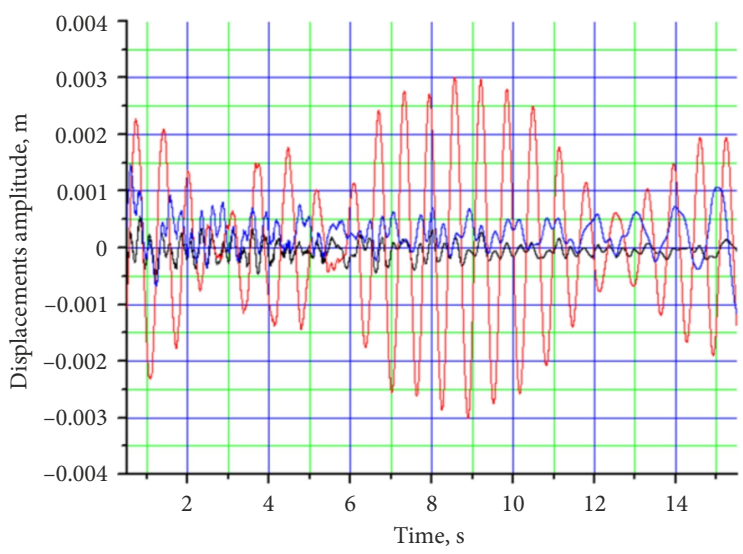

The passenger train

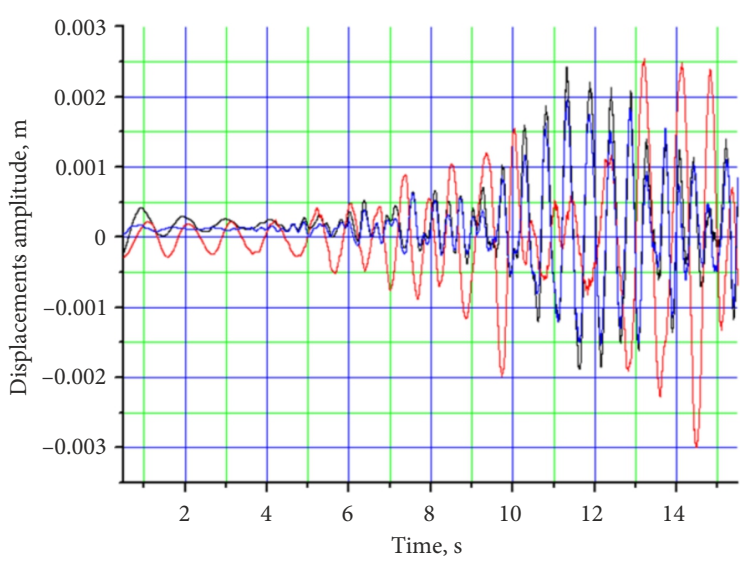

The freight train 2

Figure 16. Vertical and horizontal displacements of the midspan section of the deck subjected to different excitation: red line - vertical displacements of the downstream truss, blue line - horizontal displacements of the downstream truss, green line - vertical displacements of the upstream truss 
The values of horizontal dynamic displacements are a slightly higher. The maximum measured value is $3.28 \mathrm{~mm}$, which is greater than for the vertical oscillations. It shows that during the forced excitation, the horizontal and torsional vibrations predominate. These tendencies are particularly dangerous for railway bridges.

Excessive dynamic vibrations stimulate fatigue cracking in continuous steel structures. To reduce these consequences, the authors recommended to reduce the speed up to $80 \mathrm{~km} / \mathrm{h}$ for passenger trains, and - up to $60 \mathrm{~km} / \mathrm{h}$ for freight trains as well as to eliminate rail joints, or in the worst case, install them above the bridge supports.

During the test, additional measurements of pier vibrations of the bridge was carried out. The vibrograms of the horizontal dynamic displacements of the pier (the support 2) in the longitudinal direction of the bridge are presented in Figure 17. The maximum observed displacement value is $0.135 \mathrm{~mm}$. This again shows that the oscillation level of the support is low. The vertical displacements values are smaller and are not presented in this paper. Determined dynamic parameters (accelerations and displacements) of the support 2 shows a good physical condition of analysed pier.

\section{Conclusions}

1. The steel bridge distinguishes by a special design, applied design solutions based on the industrial coup spirit of architecture, integrated landscape and constructivism. It was those times and remains a valuable building, which requires additional studies for inspection.

2. During the field tests, free vertical vibrations of the bridge truss superstructure were excited by the shocking load and passing different trains. Three main vibrations modes were identified: $1-1.71 \mathrm{~Hz}$ (horizontal); $2-3.20 \mathrm{~Hz}$ (torsional); $3-4.21 \mathrm{~Hz}$ (vertical).

3. The vertical dynamic displacements of upstream truss in many cases are higher than displacements of the downstream truss. This is the influence of the road axis eccentricity to the bridge axis (road axis is displaced toward to the upstream truss). The maximum vertical dynamic displacement is $3.06 \mathrm{~mm}$. Maximum measured horizontal dynamic displacements value is $3.28 \mathrm{~mm}$, which is higher than for the vertical vibrations. It shows that during the forced excitation, the horizontal and rotational vibrations are dominated.

4. Dynamic vibrations stimulate the fatigue cracking of the truss members and subsequent degradation of bridge superstructure. For reduction of dynamic actions, reducing the speed for passenger trains down to $80 \mathrm{~km} / \mathrm{h}$ and for freight trains - down to $60 \mathrm{~km} / \mathrm{h}$ as well as eliminating the rail joints over the bridge deck were recommended.

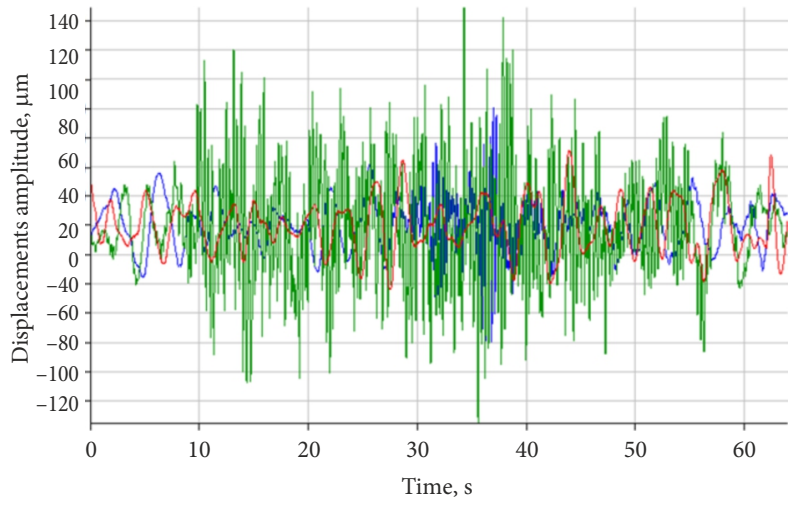

Figure 17. Longitudinal displacements of the support: red line - calm condition (maximum amplitude $0.043 \mathrm{~mm}$ ), blue line - drove locomotive (maximum amplitude $0.08 \mathrm{~mm}$ ), green line - drove freight train (maximum amplitude $0.135 \mathrm{~mm})$

5. The dynamic vibrations of intermediate support 2 are irrelevant on forced operational load excitation. The maximum acceleration amplitudes reached only: for vertical vibrations $-0.058 \mathrm{~m} / \mathrm{s}^{2}$, for horizontal vibrations $-0.126 \mathrm{~m} / \mathrm{s}^{2}$. Maximum observed horizontal dynamic displacement value is $0.135 \mathrm{~mm}$. The vertical displacement values are smaller. The identified dynamic parameters of the pier confirm its good physical condition.

\section{Acknowledgment}

The second author wishes to express his gratitude for the financial support provided by the Research Council of Lithuania (Research project No. MIP-093/2015).

\section{References}

Aničas, J. (1992). Petras Vileišis - ižymus tiltų inžinierius. Statyba ir architektūra, 6-7, 22-24 (in Lithuanian).

Bačinskas, D., Kamaitis, I. Z., \& Kilikevičius, A. (2013). A sensor instrumentation method for dynamic monitoring of railway bridges. Journal of Vibroengineering, 15(1), 176-184.

Bačinskas, D., Turla, V., Kilikevičius, A., Ragauskas, P., \& Jurevičius, M. (2014). Dynamic testing of railway truss bridge. Journal of vibroengineering, 16(6), 2649-2657. Retrieved from https://www.miestai.net/forumas/

Camara, A., Nguyen, K., Ruiz-Teran, A. M., \& Stafford, P. J. (2014). Serviceability limit state of vibrations in under-deck cable-stayed bridges accounting for vehicle-structure interaction. Engineering Structures, 61(1), 61-72.

https://doi.org/10.1016/j.engstruct.2013.12.030

Cieškaitè-Brèdikienè, L. (2008). Dizaino raida nuo Morriso iki Morrisono (374 p.). VDA leidykla (in Lithuanian).

Dormer, P. (1993). Design since 1945. New York, NY: Thames \& Hudson.

Hill, R. (2007). God's architect: Pugin and the building of romantic Britain. Allen Lane.

Jakaitis, J. (2013). Miesto erdvinio formavimo dalyviu diskursas šiuolaikines demokratijos sąlygomis (220 p.). Vilnius: Technika (in Lithuanian). https://doi.org/10.3846/2128-M 
Kamaitis, Z. (1995). Gelžbetoniniu tiltu būklè ir jos vertinimas: monografija (Condition state and assessment of reinforced concrete bridges: monograph) (182 p.). Vilnius: Technika.

Lees-Maffei, G., \& Houze, R. (2010). The design history reader. New York: Berg Publishers.

Lin, C. W., \& Yang, Y. B. (2005). Use of a passing vehicle to scan the fundamental bridge frequencies: an experimental verification. Engineering Structures, 27(13), 1865-1878. https://doi.org/10.1016/j.engstruct.2005.06.016

LST EN 1991-2:2004/AC:2010 Eurocode 1: Actions on Structures. Pt. 2, Traffic Loads on Bridges.

LST EN 1990:2004/A1:2006 Eurocode: Basis of Structural Design. „Rail Baltica“ galutinè ataskaita. (2011). Santrauka. Vilnius: „AECOM Limited“.

Ruskin, J. (1989). The seven lamps of architecture (paperback). Dover Publications.

Shiling, P., Yongle, L., Yulong, B., Xin, L., \& Shizhong, Q. (2016). Impact of train-induced vibration on railway cable-stayed bridges fatigue evaluation. The Baltic Journal of Road and Bridge Engineering, XI(2), 102-110.
Skeivalas, J., Jurevičius, M., Kilikevičius, A., \& Turla, V. (2015). An analysis of footbridge vibration parameters. Measurement 66, 222-228. https://doi.org/10.1016/j.measurement.2015.02.034

Sousa, H., Costa, B. J. A., Henriques A. A., Bento, J, Figueiras, J. A. (2016). Assessment of traffic load events and structural effects on road bridges based on strain measurements. Journal of Civil Engineering and Management, 22(4), 457-469.

Viešosios geležinkeliu infrastruktūros 2011-2012 metu tinklo nuostatai. (2010). Informacinis leidinys. Vilnius: AB „Lietuvos geležinkeliai“ (in Lithuanian).

Zambon, I., Vidovic, A., Strauss, A., Matos, J., Amado, J. (2017). Comparison of stochastic prediction models based on visual inspections of bridge decks. Journal of Civil Engineering and Management, (23)5, 553-561.

Zhai, W. M., Xia, H., Cai, C. B., Gao, M., Li, X., Guo, X., Zhang, N., \& Wang, K. (2013). High-speed train-track-bridge dynamic interactions - Part I: theoretical model and numerical simulation. International Journal of Rail Transportation, 1(12), 3-24. https://doi.org/10.1080/23248378.2013.791498 